\title{
Docking studies of flavonoid derivatives as potent HIV-1 integrase inhibitors
}

\author{
N Premjanu*, C Jaynthy, C Soniyagandhi \\ From 2nd International Science Symposium on HIV and Infectious Diseases (HIV SCIENCE 2014) \\ Chennai, India. 30 January - 1 February 2014
}

\section{Background}

HIV-1 integrase is responsible for the transfer of virally encoded DNA into the host chromosome. The process of integration occurs through 3 essential steps: formation of the preintegration viral DNA complex, 3'processing and 5 ' strand transfers. Provirus ancestral pol protein is a component of preintegration viral DNA complex, which has reverse transcriptase domain, Ribonuclease $\mathrm{H}$ like domain, integrase, $\mathrm{N}$ terminal and Zinc binding domain. To complete the integration process, strand transfer should take place. This work involves in silico prediction of the flavonoids as inhibitors of integrase activity.

\section{Methods}

$\mathrm{n}$ this experiment, docking studies were performed by modeling Pol protein: P10266 (HERV-K_5q33.3 provirus ancestral Pol protein), Q9UQG0 (HERV-K_3q27.3 provirus ancestral $P o l$ protein), Q9BXR3 (HERV-K_7p22.1 provirus ancestral Pol protein) and docking with the flavonoid compound AC1NSUMK, Quercetin 3 arabinoside and compared with Raltegravir.

\section{Results}

Docking studies illustrate the binding between the Pol protein and flavonoid compound. In docking, the interactions were found in P10266 with AC1NSUMK at GLN378, GLN338, GLY283 and TYR375 with $-7.71 \mathrm{kcal} / \mathrm{mol}$. P10266 with Raltegravir at VAL369 and THR371 with $-7.68 \mathrm{kcal} / \mathrm{mol}$ binding energy. The binding site resembles a saddle shape cleft which has positively charged residues.

\section{Conclusion}

The protein along with the AC1NSUMK with four hydrogen bonds proves to be a most stable complex inhibiting the activity of integrase. The interaction

\footnotetext{
* Correspondence: janu6kishore@gmail.com

Sathyabama University, Chennai, Tamilnadu, India

shows that it binds to the protein and specifically interferes with its strand transfer activity. Hence, this may be one of the potential candidates for inhibition of HIV activity.

Published: 27 May 2014

doi:10.1186/1471-2334-14-S3-E6

Cite this article as: Premjanu et al:: Docking studies of flavonoid derivatives as potent HIV-1 integrase inhibitors. BMC Infectious Diseases 2014 14(Suppl 3):E6.
Submit your next manuscript to BioMed Central and take full advantage of:

- Convenient online submission

- Thorough peer review

- No space constraints or color figure charges

- Immediate publication on acceptance

- Inclusion in PubMed, CAS, Scopus and Google Scholar

- Research which is freely available for redistribution
() Biomed Central 